\title{
Burger dwingt lokale politiek tot deliberatie ${ }^{*}$
}

\author{
Nico de Boer \& Jos van der Lans ${ }^{* *}$
}

We praten in Nederland sinds enkele jaren zo vaak over 'de decentralisaties' dat het net lijkt alsof er iets nieuws gaande is. Which is not. Sterker nog: er is veel voor te zeggen om zeker in het sociale domein het fenomeen decentralisatie te zien als typerend voor het beleid van de afgelopen vier decennia. Er is een gestage lokalisering van het sociale vanaf het moment dat het kabinet-Den Uyl in 1973 de Knelpuntennota liet schrijven. Die lokalisering kreeg echter veelal vorm als een met marktelementen opgetuigd agentschap van de verzorgingsstaat. Die vorm is vanaf nu uitgesloten doordat de middelen ertoe ontbreken (een bezuiniging van 4 à 6 miljard) en doordat op lokaal niveau burgers het heft in eigen hand nemen: de sociale doe-het-zelfsamenleving. De samenloop van die beide fenomenen biedt kansen voor het vitaliseren van een lokale politieke gemeenschap.

De voorgeschiedenis van de verzorgingsstaat mag bekend worden verondersteld: de voorlopers van (ver) voor de Tweede Wereldoorlog, de rapporten van Beveridge tijdens die oorlog in Groot-Brittannië en vergelijkbare rapporten elders in Europa, waaronder die van de commissie-Van Rhijn te onzent. Vervolgens het enorme wetgevingsproject (met als mijlpalen de Algemene Ouderdomswet (AOW), de Wet op de arbeidsongeschiktheidsverzekering (WAO), de Algemene bijstandswet (Abw) en de Algemene Wet Bijzondere Ziektekosten (AWBZ)), dat de jaren zestig maakt tot hét decennium bij uitstek van de verstatelijking. De korte hoogtijdagen en daarna de bijna permanente crisis.

Deels was die crisis een financiële, deels een inhoudelijke. Maar ze was in elk geval een crisis van de staat, die al snel in zijn maag bleek te zitten met de ondraaglijke verantwoordelijkheid om al die fijnmazige arrangementen centraal te sturen. Vanaf de jaren zeventig werden daarom twee wegen beproefd om de staat daarvan te bevrijden: de markt en de lokale overheid. Het jaar 1986 was daarbij een sleuteljaar. Na jarenlange pogingen tot geleide decentralisatie via rijksbijdrageregelingen en kaderwetten werd in dat jaar het rijksbudget voor welzijnswerk radicaal overgeheveld naar het gemeentefonds - zij het na een fikse korting op dat budget, met als argument dat lokale overheden zo dicht bij de burger stonden dat ze het werk vast goedkoper konden doen. De Welzijnswet (van kracht geworden in 1987) bezegelde die overheveling en was daarmee de facto een eerste vingeroefening voor de decentralisaties die straks, per 1 januari 2015, hun beslag moeten krijgen.

* Deze beschouwing is gebaseerd op het boek DEcentraal. De stad als sociaal laboratorium, dat eind februari bij uitgeverij Atlas Contact verscheen. Eerder schreven de auteurs de essays Burgerkracht. De toekomst van sociaal werk in nederland (RMO, 2011) en Burgerkracht in de wijk. Sociale wijkteams en de lokalisering van de verzorgingsstaat (Platform31, 2013).

** Drs. Nico de Boer werkt sinds 1991 als zelfstandig beleidschrijver en publicist. Drs. Jos van der Lans werkt sinds 1994 als zelfstandig journalist/publicist. www.josvdlans.nl. 
Het jaar 1986 was echter ook een sleuteljaar voor die andere weg: de markt. Op mondiaal niveau stonden neoliberalen als Reagan en Thatcher aan het roer, in Nederland was dat Lubbers, en ook bij de gemeenten was de cultuur er een waarin 'de markt' werd bejubeld als panacee. De overheid moest als bedrijf worden gerund en dat gold ook voor het vers gedecentraliseerde welzijnswerk. Tal van kleinschalige speeltuinverenigingen, buurthuizen en instellingen voor maatschappelijke dienstverlening gingen op in de grote welzijnsinstellingen die we nu kennen.

In de twee decennia na de inwerkingtreding van de Welzijnswet bleven de gemeenten die lijn volgen: als een agentschap van het Rijk voerden ze (met slechts minimale lokale variaties en op basis van beleidsgestuurde contractfinanciering) taken uit zoals ook het Rijk die zou uitvoeren, ware er geen decentralisatie geweest. Rondom het sociale domein ontstond nauwelijks politiek debat. Het ging niet om lokale bekommernis, niet om menselijke noden en capaciteiten, niet om vraagstukken van verdeling (wat doen burgers zelf, wanneer mogen ze een beroep doen op collectieve financiering?). Het debat over het sociale domein op lokaal niveau werd als het ware verengd tot een kwestie van aansturing van instellingen. Beleidsafdelingen Welzijn vroegen instellingen om offertes voor het aanbod en spreadsheets over de geleverde 'productie'. Ambtenaren speelden daarin de hoofdrol, de politiek hield zich afzijdig, of het moest zijn dat ze werd bestookt door een lobby van buurtbewoners of gebruikers van een wijkvoorziening die een incident kwamen melden: hangjongeren die zich misdroegen, een soos die moest sluiten, dreigende kastekorten bij deze of gene instelling... In zulke gevallen sloeg dan doorgaans de incident-regelreflex toe: de politiek eiste nieuw beleid, dat opnieuw door de betreffende instelling diende te worden gerealiseerd.

\section{Schaarste en overvloed}

Er zijn twee ontwikkelingen die aan die oude beleidswerkelijkheid een eind maken: de steeds nijpender schaarste van de collectieve middelen en de opkomst van een rijkdom aan burgerinitiatieven. Die schaarste is niets nieuws: prominente sociologen als Schuyt, Van Doorn en Adriaanssens waarschuwden al decennia geleden voor de onbetaalbaarheid van de verzorgingsstaat. De crisis heeft die vanaf 2008 alleen maar verscherpt. In de drie grote decentralisaties die nu op stapel staan, gaat voor 15 miljard aan rijkstaken naar gemeenten, die daar ongeveer 10 miljard aan budget voor krijgen. De verzorgingsstaat op lokaal niveau voortzetten is daarmee definitief geen optie meer.

De opkomst van burgerkracht heeft eveneens een lange voorgeschiedenis. De 19de-eeuwse voorgeschiedenis van de verzorgingsstaat is te beschouwen als een serie burgerinitiatieven (aangeduid als 'particulier' initiatief') op het gebied van zorg, sociale zekerheid, volkshuisvesting en volksverheffing. Ook de verzorgingsstaat zelf droeg bij aan de kracht van burgers door met allerlei voorzieningen een goed verzorgde en opgeleide middenklasse te creëren. Daar treedt echter een tragische paradox op: de (verzorgings)staat en de markt hebben mondige, zelfbewuste, individualistische en kritische burgers gecreëerd - maar die keren zich 
tegen de instituties. Gezag en voogdij liggen onder vuur, de behoefte om zelf voorzieningen op te zetten groeit, zeker als die behoefte gevoed wordt door de noodzaak daartoe omdat collectief gefinancierde voorzieningen verdwijnen of te duur worden. In plaats van méér-oplossingen vraagt de huidige tijd om ándereoplossingen, om duurzame innovaties. In plaats van Haags beleid vraagt de samenleving om ruimte voor eigen initiatief en maatschappelijk ondernemerschap. En juist dat maakt dat de logica van de klassieke verzorgingsstaat niet meer past op de werkelijkheid die hij zelf tot stand heeft gebracht.

Wat ervoor in de plaats moet komen laat zich niet kortweg samenvatten met het begrip 'participatiesamenleving'. Was het maar zo eenvoudig: we laten de burgers wat meer doen en klaar is Kees. In werkelijkheid is het sociaal-politieke landschap in Nederland ingrijpend aan het veranderen. De historische samenloop van de drie megadecentralisaties en de opkomst van de doe-het-zelfsamenleving maakt in potentie een einde aan de armetierige vorm van lokaal sociale politiek bedrijven die we de afgelopen decennia hebben leren kennen. Voor een deel blijft de lokale overheid het agentschap van de rijksoverheid dat landelijke regelingen uitvoert en toeziet op naleving van regels en wetten. Maar daarnaast krijgt de gemeente een 'nieuwe' taak: het organiseren van lokale deliberatie over lokale oplossingen voor maatschappelijke vraagstukken: energie, zorg, cultuur, wonen, welzijn, onderwijs, werk, noem maar op.

Het gaat niet langer meer alleen om de vraag hoe grote semioverheidsinstellingen voor welzijnswerk onder strikt toezicht de schaarse collectieve middelen mogen besteden. Er ontstaat ruimte voor veel indringender en omvattender kwesties: hoe kunnen burgers hun bekommernis vormgeven? Welke potenties hebben initiatieven van buurtbewoners, ouderen, ouders, kinderen enzovoort daarbij? Waar dreigt uitsluiting onwenselijke effecten te krijgen? Waar is een zetje in de rug nodig? Voor welke voorzieningen willen we de - noodzakelijkerwijs schaarse overheidsmiddelen inzetten? Dat is een aanzienlijk breder spectrum aan vragen dan die de afgelopen jaren op de agenda van de raadscommissie Welzijn stonden.

\section{Nieuwe wegen}

Met name de gemeenteraad kan in die verbreding een nieuwe betekenis krijgen en een bredere rol verwerven in het lokale politieke veld. De vraag is hoe. Hoe kan die bredere rol van de gemeenteraad vorm krijgen? Hoe kunnen lokale politici voorkomen dat ze in het geweld van de decentralisaties en bestuurlijke regionale onderonsjes buitenspel komen te staan?

Om te beginnen: het lijkt onontkoombaar dat gemeenten - inclusief hun raden een grotere schaal krijgen. Het realiseren van de grote decentralisaties is voor kleinere gemeenten simpelweg een te grote opgave om op eigen houtje te kunnen volbrengen. Zaken als sociale werkbedrijven en de inkoop en contractering van specialistische (jeugd)zorg kunnen nu eenmaal niet in gemeenten van pakweg 20.000 zielen worden georganiseerd. Die opschaling van bovenaf opleggen is een kansloze onderneming, zo merkte minister Plasterk al binnen een halfjaar na zijn aantreden. Van onderop werken kleine en middelgrote gemeenten echter al volop 
samen, vaak onder de bezielende leiding van een centrumgemeente. De democratische controle daarop is waarschijnlijk alleen te organiseren door ook politiek tot opschaling over te gaan, hoe groot ook het ongenoegen van veel bewoners van kleinere gemeenten zal zijn.

Om dat ongenoegen tegemoet te komen zijn er echter wel mogelijkheden: onder de paraplu van een grote(re) gemeente is politieke deliberatie op subgemeentelijk niveau goed te organiseren. De afgelopen jaren gebeurde dat bijvoorbeeld met wisselend succes in de Amsterdamse stadsdeelraden. Daar kon je veel van zeggen, maar niet dat het maatschappelijk debat daar uit de weg werd gegaan. De zeven stadsdelen functioneerden in feite als zelfstandige gemeenten in het grotere geheel van Amsterdam, zeker op het terrein van sociale activiteiten en het inspelen op initiatieven van burgers. Het is karakteristiek en ironisch tegelijk dat de rijksoverheid de hoofdstad heeft gedwongen om haar stadsdeelraden op te heffen. Vanaf maart 2013 mogen zogeheten 'bestuurscommissies' hun bestaansrecht bewijzen. Dat zijn kleinere, gekozen organen (dertien tot vijftien leden) met een klein dagelijks bestuur (maximaal drie leden) met vergaande budgetrechten, vooral op het sociale domein.

Ook veel andere gemeenten hebben de afgelopen jaren vormen van wijkgericht werken gecombineerd met vormen van politieke binnengemeentelijke decentralisatie. In veel gevallen werd gemeentelijke herindeling gevolgd door het oprichten van dorpsraden. In datzelfde kader past het werken met wijkbudgetten of bewonersbudgetten, maar ook de introductie van burgerbegrotingen, waarbij burgers rechtstreeks ideeën leveren voor en invloed uitoefenen op de besteding van gemeentelijke middelen. Zulke modellen maken het mogelijk om als kleine of middelgrote gemeente op te gaan in een groter geheel en toch sturend vermogen te beleggen bij organen die dicht bij de burger staan en zodoende de sociale agenda van dorpen, wijken en stadsdelen mede inhoud kunnen geven. Ze bieden de kans om het 'democratisch gat' te dichten waarvoor de Vereniging van Lokale Rekenkamers eerder indringend waarschuwde, zonder de politieke betrokkenheid van burgers op buurt-, wijk- en dorpsniveau weg te organiseren.

\section{Luisteren?}

Echter: geen van zulke modellen van binnengemeentelijke politieke decentralisatie garandeert die politieke betrokkenheid, daar is meer voor nodig dan een model. Macht en mogelijkheden zo dicht mogelijk bij burgers beleggen vergt een andere rolopvatting van lokale politici.

Daar is ook in het verleden al vaak op aangedrongen. Politici moesten, zo heette het als de kloof tussen burgers en bestuurders weer eens ter sprake kwam, 'beter luisteren'. In de praktijk illustreert die uitdrukking hoezeer het marktdenken het politieke denken heeft geïnfecteerd. Het marktdenken spreekt mensen aan als consumenten wier behoeften bevredigd worden door gretige leveranciers die er omwille van hun omzet alles aan doen om hun klanten tevreden te stellen. Als die mentaliteit zich vanuit de supermarkt in het politieke nestelt, wordt 'luisteren' naar de burger synoniem met: gehoorzamen, doen wat wij u opdragen. 
Die houding heeft vooral de nationale politiek in een wurggreep genomen. Bijna alle partijen proberen als ware marketeers in te spelen op de onvrede onder het volk. Aan elk van beide uitersten van het politieke spectrum claimt een populistische oppositiepartij te weten wat er onder de mensen in het land leeft: SP en PVV. Uit angst voor een afstraffing bij de volgende verkiezingen houden de partijen in het centrum hen nauwlettend in het oog. De beide populistische partijen beseffen daarbij haarfijn dat ze in een mediacratie de meeste macht kunnen uitoefenen als ze zelf niet aan de macht zijn.

Het is geen toeval dat de PVV niet of nauwelijks meedoet aan lokale verkiezingen. Landelijk is de politiek abstract, waardoor het relatief makkelijk is goede sier te maken met een vaag programma en een manier van politiek bedrijven die voortdurend suggereert voort te bouwen op de stem van het volk. In het lokale is dat veel moeilijker vol te houden: op gemeentelijk niveau zijn veel betere voorwaarden om te ontsnappen aan de wurggreep van het populisme. De lokale context is tastbaarder en betekenisvoller en biedt meer aangrijpingspunten voor burgers om er zelf verantwoordelijkheid in te nemen. De opkomst van lokale partijen, nu al met bijna een kwart van het aantal zetels de grootste stroming in de gemeenteraden, laat dat in feite ook zien. Hun succes is in veel gevallen gestoeld op een concreet lokaal onderwerp (het bouwen van dure stadhuizen of een grootschalig cultureel centrum), waarover in de gemeente veel ongenoegen bestaat.

\section{Geen landelijke schema's}

In de netwerksamenleving zijn het niet meer de knooppunten die bepalen wat voor verkeer er plaatsvindt - het is het verkeer dat bepaalt waar zich knooppunten manifesteren. De gemeenteraad kan zich die status van knooppunt proberen te verwerven door lokaal productieve botsingen te organiseren, deliberatie tussen burgers en overheidsdienaren te realiseren, enzovoort. In die context is geen behoefte aan dependances van landelijke politieke partijen, en des te meer aan politici die lokale idealen hebben en zich persoonlijk kunnen verstaan met lokale burgers. Zij zullen zich eerder manifesteren als spreekbuis van de beweging van onderop, wellicht zelfs als ambassadeurs van sociaal-doe-het-zelfinitiatieven van burgers.

Gemeentepolitiek kan daardoor een nieuwe impuls krijgen, zeker als deze politici zich ook nog eens los kunnen maken van de ambtelijke tredmolens en controlereflexen. $\mathrm{Nu}$ is de focus van vrijwel elke gemeenteraad bijna uitsluitend gericht op het door hem gekozen bestuur, dat hij immers geacht wordt te controleren en waarmee eindeloze commissie- en raadsvergaderingen worden gevuld. Maar wie de gemeenteraad weer gaat zien als een politieke arena, een publiek knooppunt waarin lokale belangen, gemeenschappen en voorzieningen elkaar treffen en burgers met elkaar debatteren, kan bij elke vergadering de deur openzetten. De gemeenteraad-nieuwe-stijl moet in de aanloop van besluitvorming naar hartenlust bestuurders, professionals en burgers kunnen toelaten tot het gesprek en waar nodig in die politieke arena ter verantwoording kunnen roepen. Zo'n 
gemeenteraad kan in het openbaar onderzoek doen, hoorzittingen organiseren, noem maar op.

In de kern gaat het daarbij nog steeds om 'luisteren', maar dan in een andere betekenis. Het gaat niet om 'gehoorzamen' aan de burger in zijn rol van kritische consument van collectief gefinancierde diensten - het gaat om betrokkenheid vanuit een specifieke overheidsrol bij burgers en professionals die eveneens publieke functies uitvoeren.

\section{Van of/of naar en/en}

Het probleem met de discussie over de term 'participatiesamenleving' is dat deze meestal blijft hangen in een of/of-groef. Of de overheid doet het, of de burgers zelf. En omdat de overheid minder doet, moeten de burgers meer doen. In de lokale werkelijkheid zeggen zulke clichés bitter weinig. Daar gaat het niet om algemene schema's, maar juist om de concrete condities waarin op lokaal niveau alle betrokkenen een andere rol kunnen gaan vervullen: burgers en overheid.

Het is een taak van de overheid (en dus van de politiek) om de voedingsbodem voor burgerinitiatieven zo vruchtbaar mogelijk te maken. Dat kan door initiatieven van burgers toegang te geven tot geld en/of ruimte tegen betaalbare prijzen (slow capital); dat kan door slimme beloningssystemen, bijvoorbeeld huurkorting voor bewoners die publieke taken in buurten verrichten; dat kan door het beleggen van rechten zoals het right to challenge, het right to bid, het right to build. Of - we wezen er al eerder op - door het werken met burgerbegrotingen, wijkbudgetten, burgerpanels enzovoort.

Voor het antwoord op dat type maatschappelijke vragen bestaat geen nationaal receptenboek. De drie decentralisaties luiden ook het afscheid in van de klassieke overheidsinnovatiestrategieën met nationale programma's en lokaal uit te rollen blauwdrukken. Geen burger die daarom rouwt. 